\title{
Covid-19: Government appoints former Olympics chief to lead PPE production drive
}

\section{Abi Rimmer}

The BMJ

The former head of the 2012 Summer Olympics and Paralympics has been appointed to lead the UK's effort to produce personal protective equipment (PPE) for NHS staff.

Paul Deighton will lead a campaign to scale up domestic PPE manufacturing, said the Department of Health and Social Care.

Matt Hancock, England's health and social care secretary, said, "Lord Deighton led the delivery of the Olympics. Now he will lead a singular and relentless focus on PPE as the country's top manufacturing priority, with the full weight of the government behind him."

The government said that it had issued a "call to arms" for industry to make essential PPE that meets its technical specifications. Companies such as Burberry, Rolls-Royce, McLaren, Ineos, and Diageo have already started work to produce equipment including gowns, visors, and hand hygiene products.

The news comes after the BMA revealed that it had been contacted by over 70 private companies that have offered PPE to the NHS but have not had a response from the government. The association also released the results of a survey completed by 6126 of its members from 14 to 16 April.

The results show that, of 1536 doctors who commented, $37 \%$ (567) were facing a shortage of FFP3 masks. When asked about long sleeved gowns, $44 \%$ of respondents (670 of 1525) said that they had shortages, and $46 \%$ of respondents (710 of 1530) did not have enough full face visors.

\section{Not reaching doctors}

Chaand Nagpaul, BMA council chair, said, "The government says that one billion items will soon have been shipped, and, while there have been signs of improvement, our research clearly shows that equipment is not reaching all doctors working on the front line.

"Meanwhile, the BMA has been inundated with approaches from companies offering to do their bit to supply the NHS. This is a truly sorry state of affairs, and we renew our call for the government to work with manufacturers to ramp up domestic supply."

Responding to Deighton's appointment, Niall Dickson, chief executive of the NHS Confederation, which represents healthcare organisations, said, "Lord Deighton's appointment is the right one, but this really is a national effort and we need a relentless focus on upscaling fluid repellent gown supplies in particular. The challenge before him and us is an Olympic one, to ensure that the PPE made available for health and care staff meets the gold standard."

The health department said that the government was working around the clock to give the social care sector and the wider NHS the equipment and support they needed to tackle this outbreak. It said that, as of 16 April, it had delivered almost a billion pieces of PPE around the country. 